THERE has been a slight eruption of Vesuvius for some days.

A VERY distinct Fata Morgana was observed above the village of Zhor, near Kozlau in Bohemia, on the 2nd inst.

M. Jules FerRy, the French Minister for Public Instruction publishes a report on the re-establishment of the Museum of Pedagogy, which was created by $M$. Jules Simon at the Ministry of Public Instruction, and described in NATURE at the time. This report shows that the original idea of such a collection must be attributed to M. Jullien of Paris, one of the best pupils of the celebrated Pestalozzi, who established it in 1817 . The direction of the new museum will be given to a general inspector of primary instruction specially appointed for the purpose. This museum will be also a central library for primary education in France.

We have received two numbers (February and March) of the College Fournal, issued in connection with the Georgetown (R.C.) College, U.S. The latter number contains an article resuming some of the more recent conclusions with regard to sun-spots.

WE have on our table the following books :- "Description of Vertebrate Remains," Prof. Joseph Leidy (Collins, Phila." delphia); "Characeæ Americanæ," part I (Timothy F. Allen, New York; "Sport in British Burmah, Assam, and the Cassyah and Jyntiah Hills," Lieut. Col. Pollok (Chapman and Hall); "Obituary Notices of Astronomers," Edwin Dunkin (Williams and Norgate); "On the Nature of Life," Ralph Richardson (H. K. Lewis); "The Gault," F. G. Hilton Price (Taylor and Francis); "Ausgestrahlte Licht," Edw. L. Nichols (E. V. Huth, Göttingen); "The Students' Text-Book of Electricity," Henry M. Noad (Crosby Lockwood); "Atlas of Histology," part 3, E. Klein and E. N. Smith (Smith, Elder); "Organic Chemistry," Hugh Clements (Blackie and Sons); "Evolutions Old and New," S. Butler (Hardwicke and Bogue); "Treatise on Natural Philosophy," vol. i. part I, Thomson and Tait (Cambridge University Press); "Mechanics," R. S. Ball (Lon gmans); "Health and Occupation," B. W. Richardson (S.P.C.K.); "Electric Lighting," J. N. Shoolbred (Hardwicke and Bogue); "Hydro-Incubation," Thos. Christy (Christy and Co.); "Principles of the Algebra of Logic," Alex. Macfarlane (Douglas); "Geological Map of Northumberland," G. A. Lebour (Andrew Reid); "The Ibis" (General Index 1859-76), Ed. O. Salvin (Van Voorst); "Middletøn's Impeachment of Modern Astronomy" (Judd and Co.); "Hints on the Pronunciation of the French Language," L. J. V. Gerhard (Hachette and Co.); "Analytical Chemistry," Dr. John Muter (Wm. Baxter); "Pharmaceutical Chemistry," Dr. John Muter (Wm. Baxter); "Manchester Science Lectures for the People, 1877,1878 , 1879" (John Heywood); "Australasia," A. R. Wallace (E. Stanford).

THE additions to the Zoological Society's Gardens during the past week include a Rhesus Monkey (Macacus erythraus) from India, presented by $\mathrm{Mr}$. H. Winsor; a Vulpine Phalanger (Phalangista vulpina) from Australia, presented by Mr. A. Elder; a Ring-necked Parrakeet (Palcornis torquatus) from India, presented by Mr. F. S. Prince; a Herring Gull (Larus argentatus), European, presented by Mr. C. H. de Loecker; a Rough Terrapin (Clemmys punctularia) from Trinidad, presented by Surgeon-Major C. J. Weir; a Puma (Felis concolor) from America, purchased; two Squirrel Monkeys (Saimaris sciurea) from Guiana, two Plantain Squirrels (Sciurus plantani) from Java, a blue Jay (Cyanocitta cristata) from North America, an Ariel Toucan (Ramphastos ariel) from Brazil, a Sclater's Curassow (Crax sclateri) from South America, deposited; a Zebu (Bos indicus), two Geoffroy's Doves (Peristera geoffroyzi), a Yellowlegged Herring Gull (Larus leucophous), bred in the Gardens.

\section{ON THE INFLUENCE OF PRESSURE UPON THE SPECTRA OF GASES AND VAPOURS}

HERR G. CIAMICIAN has recently communicated to the Vienna Academy the results of a series of interesting experiments made with a view of investigating the influence of pressure upon the spectra of gases and vapours. From the somewhat lengthy report we gather the following data, which may prove acceptable to those of our readers who are actively engaged in spectroscopic research. The spertra of the three halogens, chlorine, bromine, and iodine, show on the whole the same peculiarities when the pressure is increased. The bright lines become diffused, sometimes a little broader, without, however, changing into bands. Besides this, a continuous illaminated background appears, which increases in brightness with the pressure, and which often overpowers the lines. This is particularly the case with iodine, where, eventually, nothing but a continuous spectrum is seen; while with chlorine and bromine certain lines yet remain brighter than the continuous light. The behaviour of certain lines in the red part of the spectra of chlorine and bromine is remarkable, as they retain their original sharpness and fineness under any pressure.

The spectrum of sulphur does not change at all under increased pressure, the lines retain their full sharpness, and a continuous bright background appears only at the red end of the spectrum. In the case of phosphorus and arsenic there is no reaction at all, as here even the continuous background does not appear. Herr Ciamician thinks that it has been overlooked hitherto that arsenic under a moderate pressure, and without a Leyden jar being inserted into the electric current, gives a spectrum of the first order, viz., a nearly continuous one, which, when the density becomes greater and the Leyden jar is inserted, disappears, and is replaced by a line spectrum.

Metals behave very differently to the non-metals just mentioned; here a real band-like extension of the spectral lines. takes place, while the continuous light remains subdued. In the mercury spectrum the enlargement of the green and violet lines are specially noteworthy. In the sodium spectrum Herr Ciamician could observe the enlargement, which is very considerable, only with the reversed, i.e., dark D line, as he could not observe the spectrum emitted in any other way than through a layer of sodium vapour. Under high pressure sodium gives a continuous background in the immediate neighbourhood of the $D$ line, and upon this the reversed $D$ line appears. At first it is seen as a double line, but soon afterwards the two lines flow into one in consequence of the enlargement; the dark band thus formed becomes wider and wider, until it finally covers the whole background which appeared in continuous light.

\section{SCIENTIFIC SERIALS}

THE Revue Internationale des Sciences (April, 1879) contains the following papers:-On symbiosis, by Prof. de Bary.On the physical and intellectual evolution of woman among the different races, by $M$. Zaborowski. $-O n$ the chromatic function of the octopus, by Dr. L. Frédéricq.-On the source of muscular power, by A. Flint.-On the constitution of the blood plasma, by Dr. L. Frédéricq.-On the nature of lichens, by Dr. J. Muiller.-- On the entozoa of insects, by Osman Galeb.

THE Verhandlungen der naturforschenden Gesellschaft zu Freiburg in Baden (vol. vii. part 3) contains the following papers :- On a generalisation of Jacobi's reversion problem of Abel's integral, by $F$. Lindemann.-On the determination of the coefficient of elasticity through the bending of short rods, by K. R. Koch.-Microscopical observations on the growth and melting away of alum crystals in solutions of isomorphous substances, by F. Klocke. - On an automatic water and air-pump, by L. von Babo.-New discoveries in the Freiburg flora, by J. Schill.-On some minor actions of wind, by F. C. Henrici.

TuE Archives des Sciences physiques et naturelles (April, 1879) contains the following papers:--Remarks on the geological review of Switzerland for 1878 , by Ernst Favre.-On the seiche occasioned by the cyclone of February 20 last, by Prof. Ph. Plantamour.- On the hurricane of February 20 , by F. A. Forel.- - On the presence of tannine in vegetable cells, by J. B. Schnetzler. $-\mathrm{On}$ the meteorology of the Presidency of Bombay, by $\mathrm{Cb}$. Chambers.-Researches on electricity, by Gaston Planté.-On the compounds derived from oxypropyluenzois acid, ing $R$. 